\title{
Kolaborasi Antara PT Gas Negara Dengan Pemerintah Kota Yogyakarta Dalam Mewujudkan Smart City
}

\author{
Lenny kurniasari ${ }^{1}$, Eko Priyo Purnomo ${ }^{2}$, Lubna Salsabila ${ }^{3}$ \\ Program Studi Ilmu Pemerintahan, FISIPOL, Universitas Muhammadiyah Yogyakarta, Indonesia \\ Email: lennykurniasari03120@gmail.com
}

\begin{abstract}
This study aims to describe the form of collaborative governance between the Government of Yogyakarta City and the business sector, namely PT Gas Negara in realizing smart cities. The focus of this research is to describe the process of cooperation between the two parties (Government and Private) so that a memorandum of understanding is created to support smart city. This study uses the cross-sector collaboration theory of John M Bryson and Barbara C. Crosby who mentioned collaborative governance must pay attention to the process. This study uses a qualitative patterned research method, while the data from this study are obtained through participant observation, indepth interviews, document analysis, media and literature. Data in this study were analyzed using data triangulation techniques. Following are some of the findings from this study. First, PT Perusahaan Gas Negara Tbk signed a memorandum of understanding with the Yogyakarta City Government in supporting the smart city program by providing infrastructure and utilizing natural gas as an alternative energy source. Second, PT PGN developed the PGN 360 Degree Integrated Solution service as a follow-up to the provision of electronic-based services and thirdly, the Yogyakarta City Government utilized the ICT services / provider of optical fiber networks owned by PT PGN as a support for smart cities.
\end{abstract}

Keywords: Smart city, PT Gas Negara, Collaboration Governance.

\begin{abstract}
ABSTRAK
Studi ini bertujuan mendeskripsikan bentuk tata kelola pemerintahan kolaboratif antara Pemerintah Kota Yogyakarta dengan sektor bisnis yakni PT Gas Negara dalam mewujudkan smart city. Fokus penelitian ini adalah menjabarkan proses kerjasama antar kedua belah pihak (Pemerintah dan Swasta) sehingga terciptanya nota kesepakatan mendukung smart city. Studi ini menggunakan teori cross-sector collaboration John M Bryson dan Barbara C. Crosby yang menyebutkan tata kelola pemerintahan kolaboratif harus memperhatikan proses. Studi ini menggunakan metode penelitian bercorak kualitatif, adapun data dari studi ini didapatkan melalui observasi partisipan, wawancara mendalam, analisis dokumen, media dan pustaka. Data dalam studi ini dianalisis menggunakan teknik triangulasi data. Berikut beberapa temuan dari studi ini. Pertama, PT Perusahaan Gas Negara Tbk menandatangani nota kesepahaman dengan Pemkot Yogyakarta dalam menunjang program smart citymelalui penyediaan infrastruktur dan pemanfaatan gas bumi sebagai sumber energi alternatif. Kedua, PT PGN mengembangkan layanan PGN 360 Degree Integrated Solution tindak lanjut penyediaan layanan berbasis elektronik dan ketiga, Pemkot Yogyakarta memanfaatan layanan ICT/ penyedia jaringan fiber optik milik PT PGN sebagai penunjang smart city.
\end{abstract}

Kata kunci : Smart City, PT Gas Negara, Collaborative Governance.

53 Kolaborasi Antara PT Gas Negara Dengan Pemerintah Kota Yogyakarta... 


\section{Noken Volume 5 ( 1 ) Halaman : 53-66 2019}

\section{PENDAHULUAN}

Konsep perkembangan tata kelola pemerintahan saat ini, kemajuan teknologi informasi maupun teknologi digital telah dapat merubah salah satu nilai dari pembaharuan yang ada, berbicara tentang kerkembangan teknologi digital tidak terlepas dari kata smart city.Seperti kita ketahui bersama bahwa konsep smart city merupakan isu global yang sedang dibicarakan hampir diseluruh dunia.Baik oleh Negara maju maupun Negara berkembang seperti Indonesia.

Berkembangnya smart city di Indonesia tidak luput dengan arus modernisasi perkemabangan teknologi informasi khususnya di wilayah-wilayah urban perkotaan seperti Kota Yogyakarta. Perkembangan teknologi informasi dan komunikasi (TIK) telah mengubah bagaimana individu, organisasi dan pemerintahan bekerja.upaya untuk menciptakan suatu kota yang layak huni, secara aman dan juga nyaman bagi warganya juga dapat meningkatkan kualitas yang dimiliki di suatu kota dilihat dari hal pendapatan masyarakat dikota tersebut. Sehingga tujuan smart city tersebut adalah sebagai salah satu faktor lingkungan (kenyamanan), masyarakat yang mampu mengelola ekonomi dengan naik (daya saing) dan dalam dimensi sosial (keamanan) masyarakat yang dapat terjamin.

Menurut hasil survey yang dilakukan oleh Asosiasi Penyelenggara Jasa Internet Indonesia (APJII), pengguna internet pada tahun 2017 sejumlah 142,26 juta orang. Angka tersebut setara dengan $54,68 \%$ jumlah penduduk Indonesia sebesar 262 juta jiwa. Keadaan ini meningkat dari tahun 2016 yakni sekitar 132,7 juta jiwa (APJII, 2018) dalam (Iqbal, 2019). Konsep smart city atau kota pintar pada saat ini sudah dikenal dikalangan masyarakat secara popular. Beberapa konsep secara menyeluruhan dari smart city yang ada diindonesia yaitu terdapat 6 (enam) konsep smart city atarannya: smart living, smart mobility, smart economy, smart people, smart environment, dan juga smart governance. Dari beberapa konsep tersebut didukung dengan adanya keterlibatan teknologi informasi, dalam pengimplementasian disuatu kota masingmasing pun masih memperhatikan pada fokus berbeda yang ada di dalam proses membangun kota yang akan menjadi kota yang pintar (Annisah, 2017).

Namun secara etimologis menurut Manan dkk, konsep dasar pada smart city dapat dilihat dari tercapainya suatu perubahan disekitar lingkungan bernegara 
pada masyarakat secara efisien, memberikan rasa aman dan juga tetep berkelanjutan, konsep pada smart city tertuang dalam penyusunan kebijakan publik, perencanaan dan juga pelayanan (Manan Sureshchandra, Jaydev Bhavsar, 2016). Seiring dengan pesatnya pembangunan perkotaan membuat masalah yang terjadi pada beberapa kota besar khususnya Kota Yogyakarta menjadi semakin kompleks. Beberapa masalahseperti maraknya kenakalan remaja, kerusakan infrastruktur, serta permasalahan lain menjadi permasalahan yang semakin klasik. Pemerintah Daerah tentu dituntut untuk menjadi suatuorganisasi yang dapat memaksimalkan potensi yang dimiliki daerahnya tanpa mengkesampingkan beberapa permasalahan yang muncul didaerahnya tersebut. Salah satu solusi efektif dalam pemecahan masalah tersebut adalah dengan menerapkan konsep Smart City. Kalangan masyarakat luas memandang smart city hanya sebatas seberapa banyak kota memproduksi aplikasi yang dapat diakses oleh masyarakat. Namun lebih dari itu penerapansmart city membutuhkan banyak interaksi dari kalangan masyarakat luas dengan kalangan pemerintah daerah terkait.
Kota Yogyakarta menyambut adanya konsep Smart City dengan mengimplementasikan e-government dalam ruang lingkup tata kelola pemerintahanya. Dalam rangka menyongsong pengimplementasian $e$ government Pemerintah Kota Yogyakarta mengeluarkan sebuah PeraturanWalikota Nomor 15 Tahun 2015 yang berisikan roadmap pengembangan e-government dalam ruang lingkup Kota Yogyakarta. Dalam perencanaan yang tertuang dalam Peraturan Walikota Nomor 15 tersebut meliputi beberapa tahapan diantaranya : penguatan infratruktur jaringan, penguatan infrastruktur sistem informasi, inyegrasi data dan pengembangan aplikasi, data warehouse, kebijakan menuju smart city.Setidaknya sejak 2018 hingga sekarang Kota Yogyakarta sudah memiliki platform smart city yakni Jogja Smart Service (JSS) yang memudahkan public memantau, mengadu dan mendapat layanan dari bidang terkait, dan Jogja bike.

Menurut asas otonomi, pemerintah daerah diarahkan mempercepat pencapaian kesejahteraan masyarakat, diantaranya melalui peningkatan pelayanan dan peran serta masyarakat. Salah satu tantangan pemerintah daerah yaitu memberikan layanan kepada masyarakat yang responsif dimana menekankan pelayanan publik untuk urusan wajib. Smart city telah 
diterapkan dibeberapa kota di Indonesia. Dimana smart city hadir untuk membantu menangani permasalahan yang kompleks di kota dengan pemanfaatan teknologi informasi, hingga memberikan kemudahan bagi masyarakat (April Insani, 2017).

Menurut Rahim dan Haq definisi smart city sangatlah beragam dengan istilah dan kondisi situasi yang berbeda dalam cara penerapannya. Terdapat enam dimensi dalam smart city yaitu ada smart people,smart living, smart economy, smart mobility, smart environment, dan juga ada smart governance yang memiliki peran atau fokus masing-masing dalam membangun kota yang smart (Rahim \& Haq, 2018). Memanfaatkan teknologi informasi dan komunikasi, ini memudahkan para aktor petabat tinggi pemerintahan untuk dapat langsung berinteraksi secara langsung kepada warga masyarakat sekitar, dan upaya pemerintah juga sebagai memanfaatan teknologi informasi adalah sebagai system pengawasan pada infrastruktur yang sedang terjadi disuatu kota tersebut, dengan melihat bagaimana suatu kota itu berkembang, bagaimana suatu kota dapat berkembang dan mencari jalan keluar dari suatu permasalahan kota yang sedang dihadapi secara bijaksana tanpa merugikan masyarakat (Fauzan, 2016) dan (Setiawan, 2017).
Selain untuk media komunikasi bertemunya negara dengan masyarakat smart city juga diharapkan mampu mendobrak pelayanan-pelayanan publik yang berbelit dan menciptakan inovasi. Misalnya, proses perizinan dan lain-lain, sebagaimana eko priyo dkk dalam (Wulandari et al., 2019). Dengan memanfaatkan teknologi informasi secara maksimal di sekitan pemerintah daerah. Penerapan konsep smart city ini diharapkan mampu menunjang pemenuhan kebutuhan masyarakat dan juga diharapkan mampu menyelesaikan permasalahan yang dihadapi di sekitar kota tersebut dari beberapa aspek seperti kesehatan, kesejahteraan, pendidikan dan aspek perting lainnya (Nawawi, Ilham, \& Setiawan, 2019).

Dalam menunjang pelaksanaan smart city pemerintah kota Yogyakarta juga tidak bisa bekerja sendiri. Sebagaimana Lucas (2018) dalam (Purnomo, 2019)yang menyampaikan prinsip-prinsip strategis pembangunan smart city yakni:Pertama: Teknologi yang diciptakan dalam pembangunan berkelanjutan melibatkan kolaborasi antar individu dan organisasi, Kedua: Kolaborasi antar sektor publik dan swasta, untuk memberikan layanan yang baik berdasarkan kebutuhan masyarakat, Ketiga: Komitmen dan konsistensi 
pemerintah yang tercermin dalam prioritas pembangunan kota atau visi dan tujuan kota, Keempat: Membangun perencanaan strategis yang kolaboratif dengan para pemangku kepentingan untuk menghasilkan kerangka kerja strategis jangka panjang sebagai pedoman transformasi kota, kelima: Menciptakan transformasi dan inovasi teknologi digital dengan kolaborasi antar individu dan organisasi, keenam: Memanfaatkan TIK sebagai domain aplikasi yang terintegrasi.

Collaborative merupakan bentuk kerja sama, interaksi, kompromi dari beberapa elemen yang terkait baik individu, lembaga maupun pihak-pihak yang terlibat secara langsung dan tidak langsung yang menerima dari suatu akibat dan manfaat yang secara langsung dirasakan (Arifin dan Dewi, 2018). Menurut Morales dan Mekk langkah dalam suatu collaborative governance atau kerjasama yang dilakukan antara pihak terkait adalah pelaksanaan suatu tujuan untuk mewujudkan tercapainya smart city terdapat tata kelola yang mengatur kerja sama tersebut dalam pekerjaan sehari-hari termasuk dalam berkolaborasi dengan semua pemangku kepentingan yang berfokus pada suatu program seperti, pengumpulan data dan penetapan kebijakan dan pelaksaan semua pihak yang terkait dengan pembentukan jaringan pemerintahan. Jaringan tersebut terdiri dari pemerintah kota yang dapat bertanggung jawab yang berkaitan dengan politik lingkungan dan jaringan secara keseluruhan (Morales \& Meek, 2019).

Sedangkan menurut Balogh untuk menwujudkan collaborative governance harus mempertimbangan bentuk legitimasi dan elemen kepemimpinan yang mendukung. Asumsi ini sejalan dengan apa yang disamaikan oleh (Emerson, Nabatchi, \& Balogh, 2011). Selain legitimasi collaborative governance juga harus memperhatikan dimensi kelembagaan. Dilihat dari permasalahan secara komplek disedang dialami masyarakat, seperti program yang telah berlangsung tetapi tidak memberikan jawaban dari suatu masalah, ini mengacu pada tata kelola birokrasi yang belum efektif. Hal ni membuktikan bahwa system suatu program dari kelembagaan belum dapat terselesaikan secara maksimal antara interaksi sosial dengan pihak-pihak terkait sebagai upaya pendorong dari visi dan misi suatu collaborative(Febrian, 2016).

Sementara teori yang digunakan dalam untuk melihat bagaimanakah sebetulnya kerjasama yang dilakukan antar Stakeholders dengan pemerintah daerah yang terkait, khususnya PT Perusahaan Gas Negara Tbk (PGN) 
dengan Pemerintah Kota Yogyakarta dalam mewujudkan smart city adalah teori collaborative governance atau kerjasama dalam menjalankan tatakelola pemerintahan. Menurut Emerson collaborative mendefinsikannya sebagai suatu proses dan juga stuktur dari pengambilan dalam kebijakan publik dan tata kelola pemerintahan dengan melibatkan masyarakat, NGOs swast, dari beberapa institusi yang terkait dan tingkatan yang telah ada untuk menentukan tujuan bersama karna permasalahan ini sulit untuk dirumuskan sendiri tanpa keterlibatan pihak lain (Oliver, 2013).

Paradigma lain tentang collaborative governance dikemukakan oleh Purnomo mengemukakan bahwa kerjasama mencakup beberapa dimensi: Pertama, mencakup cooperation untuk membangun kebersamaan, meningkatkan konsistensi, dan meluruskan aktivitas antar aktor. Kedua, kerjasama bisa juga merupakan sebagai proses negosiasi, yang mencakup suatu persiapan untuk berkompromi dan membuat kesepakatan. Ketiga, bisa juga merupakan bentuk antisipasi bersama melalui serangkaian aturan terhadap kemungkinan kekeliruan yang akan terjadi. Keempat, kerjasama juga bisa merupakan kekuasaan dan paksaan, kemampuan untuk mendorong hasil. Kelima, kerjasama mencakup komitmen masa depan dan intensitasnya, perencanaan atau persiapan untuk meluruskan aktivitas-aktivitas yang akan dilakukan. Dan terakhir, kerjasama mencakup keterlibatan, proses pengembangan motivasi internal dan komitmen personal terhadap proyek yang akan dikerjakan (Purnomo dkk, 2018).

Model lainnya adalah model yang cukup terkenal yang dipopulerkan John M dengan mendefinisikan cross-sector collaboration. Dan di dalam penelitian ini teori tersebut akan digunakan khusunya di dalam tahapan proses. Dimana collaborative governance yang terdiri yaitu: memperhatikan konsisi awal, tata kelola pemerintahan, kendala, struktur dan lebih akuntabilitas fokus pada suatu tujuan utama.

Fokus yang ada di dalam penelitian ini akan mengexplorasi dari sisi proses yang dilakukan termasuk dari; (1) forging agreements yang dilakukan melalui berjanjian dari suatu kesepakatan atar stakholders untuk melakukan kerjasama secara tanggung jawab, (2) building leadership adalah perlu adanya kepemimpinan yang maumpu memperhatikan fungsi baik formal ataupun informal sebagai komite atau system dari kerjasama yang dilakukan tersebut, (3) building legitimacy dimana pentingnya 
membangun legitimasi dengan adanya struktur, proses, dan strategiyang relevan dengan keadaan di sekitarnya, (4) building trust adalah upaya menumbuhkan dan menjaga kepercayaan yang dilakukan antara stakholders yang bekerjasama dan ini sifatnya sangat penting sekali di dalam collaborative governance, (5) managing conflict, adalah suatu tata kelola dasar untuk menghadapi suatu konflik yang adan

\section{METODE}

Penelitian menggunakan metode penelitian kualitatif, untuk menjelaskan, memahami, dan menggambarkan bagaimana keterlibatan pemerintah Kota Yogyakarta dan swasta yakni PT PGN berkolaborasi mewujudkan smart city. Data yang dikumpulkan melalui observasi partisipan, wawancara mendalam dengan aktor kunci, analisis dokumen, media cetak

\section{HASIL DAN PEMBAHASAN}

\section{Yogyakarta Kota Pintar: pentingnya mewujudkan smart city}

Kota Yogyakarta dikenal sebagai kota budaya, kota pendidikan, kota pariwisata dan kota perjuangan didasarkan pada sektor yan mendominasi. Kota Yogyakarta merupakan ibu Kota Daerah Istimewa Yogyakarta, yang terletak dibagian tengah, tepatnya diantara Kabupaten Bantul dan terjadi di dalam suatu system kerjasama pada saat kerjasama itu sedang berlangsung, dan (6) planning, yaitu suatu tingkatan tahapan yang sangat diperhatikan atau juga dapat dikatakan sangat penting sebagai menentukan tujuan, visi, misi, pelaksanaan tahapan, adapun keterlibatan dan peran dari masing-masing stakholders, sehingga planning ini sangat menentukan keberhasilan dari kerjasama.

dan elektronik, serta pustaka terkait lainnya. Data dalam studi ini dianalisi menggunakan teknik tringaulasi data.Secara eksplisit studi ini akan menjelaskan dua bagian: bagian pertama akan membahas pentingnya mewujudkan smart city, kedua, tata kelola pemerintahan kolaboratif antara Pemerintah Kota Yogyakarta dengan PT Gas Negara/PGN.

Kabupaten Sleman. Letaknya yang strategis menjadikan Kota Yogyakarta sebagai pusat pelayanan publik, kegiatan ekonomi dan pelayanan sosial budaya.

Kota Yogyakarta terdiri dari 14 kecamatan, 45 kelurahan, 616 rukun warga (RW), 2.532 rukun tetangga (rt) sebagaimana sebaran wilayahnya sebagai berikut: 


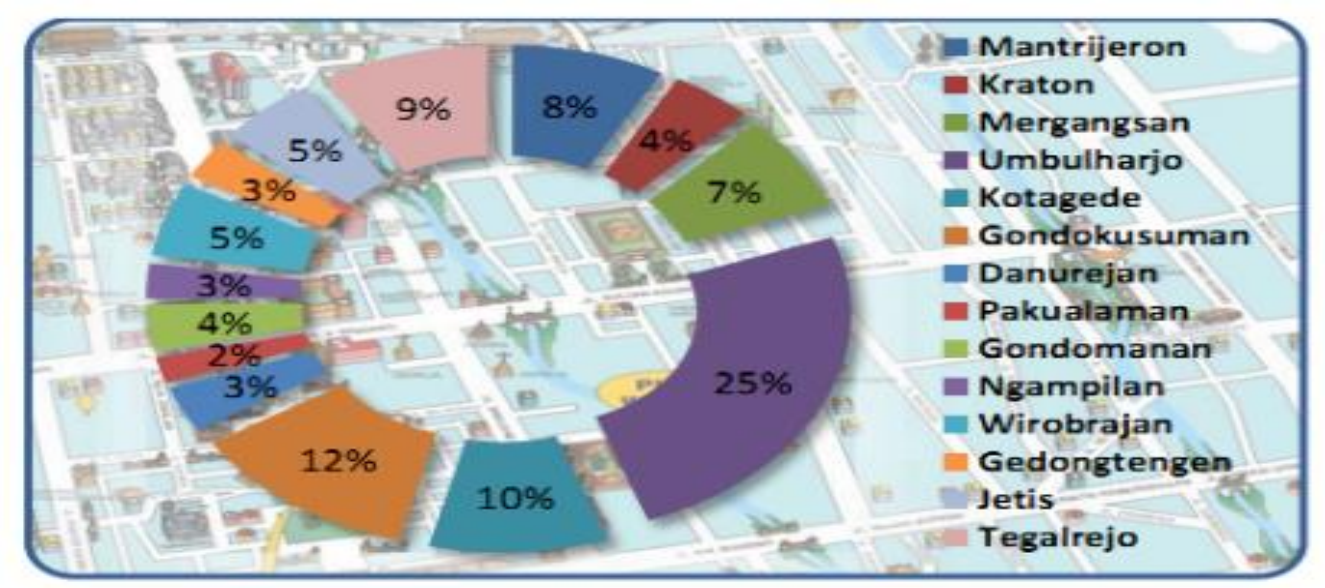

Sumber: RPJMD Kota Yogyakarta 2017-2022

Gambar 1. Sebaran Wilayah Kota Yogyakarta Berdasarkan Kecamatan

Dalam RPJMD Kota Yogyakarta tahun 2017-2022 pengembangan Kota Yogyakarta terfokus pada pemanfaatan teknologi informasi (TIK) dengan konsep JOGJA SMART CITY. Konsep ini akan menempatkan Kota Yogyakarta sebagai kota cerdas yang merupakan pengembangan sistem pengelolaan pemerintah secara daring dan terkoneksi dengan khalayak. Sebagaimana visi pemerintah Kota Yogyakarta: mewujudkan Visi Pembangunan Kota Yogyakarta melalui layanan yang efektif, efisien, transparan, akuntabel, dan partisipatif yang dikelola secara terintegrasi dan berkelanjutan dengan dukungan teknologi untuk keberdayaan masyarakat.

Fokus pengembangan smart city Yogyakarta setidaknya ada 6 indikator (semart governance, smart branding, smart economy, smart living, smart society, smart environment).Smart city di Kota
Yogyakarta dibangun dan dikembangkan sebagai salah satu dari 12 prioritas RPJMD. Pada tahap awal sebagai bagian perwujudan smart city Kota Yogyakarta menetapkan program-program inovasi yang dikemas dalam quick wins diantaranyaJogja Smart Service (JSS) yang menjadi portal utama smart city Kota Yogyakarta.

Adapun layanan yang diberikan berupa jasa, administrasi dan data informasi secara online melalui aplikasi single ID, single on dan single windows untuk mempercepat proses pelayanan kepada masyarakat. JSS terkoneksi langsung dengan OPD terkait, sehingga masyarakat dapat mengaksesnya dengan mudah dan dapat melakukan pengawasan pasrtisipatif kepada penyelenggara kebijakan publik. 


\section{Noken Volume 5 ( 1 ) Halaman : 53-66 2019}

Pengembangan smart city Kota Yogyakarta bukanlah omong kosong semata, hal ini dapat dibuktikan tingkat partisipasi masyarakat yang terus meningkat sejak di cetuskannya program ini. Data pada Juni 2018 hingga Juli 2019 pengguna smart city sebanyak 18.843 pengguna, dan dilihat dari banyaknya populasi di Yogyakarta yakni 417.705. penggunaan sistem ini bukan hanya dilakukan oleh masyarakat lokal saja, melainkan mahasiswa, wisatawan dan masyarakat di luar Kota Yogyakarta. Partisipasi dari masyarakat sebagian besar berisikan dukungan terhadap pemerintah, aspirasi atau saran atas pelayanan publik serta infratruktur di wilayah Kota Yogyakarta.

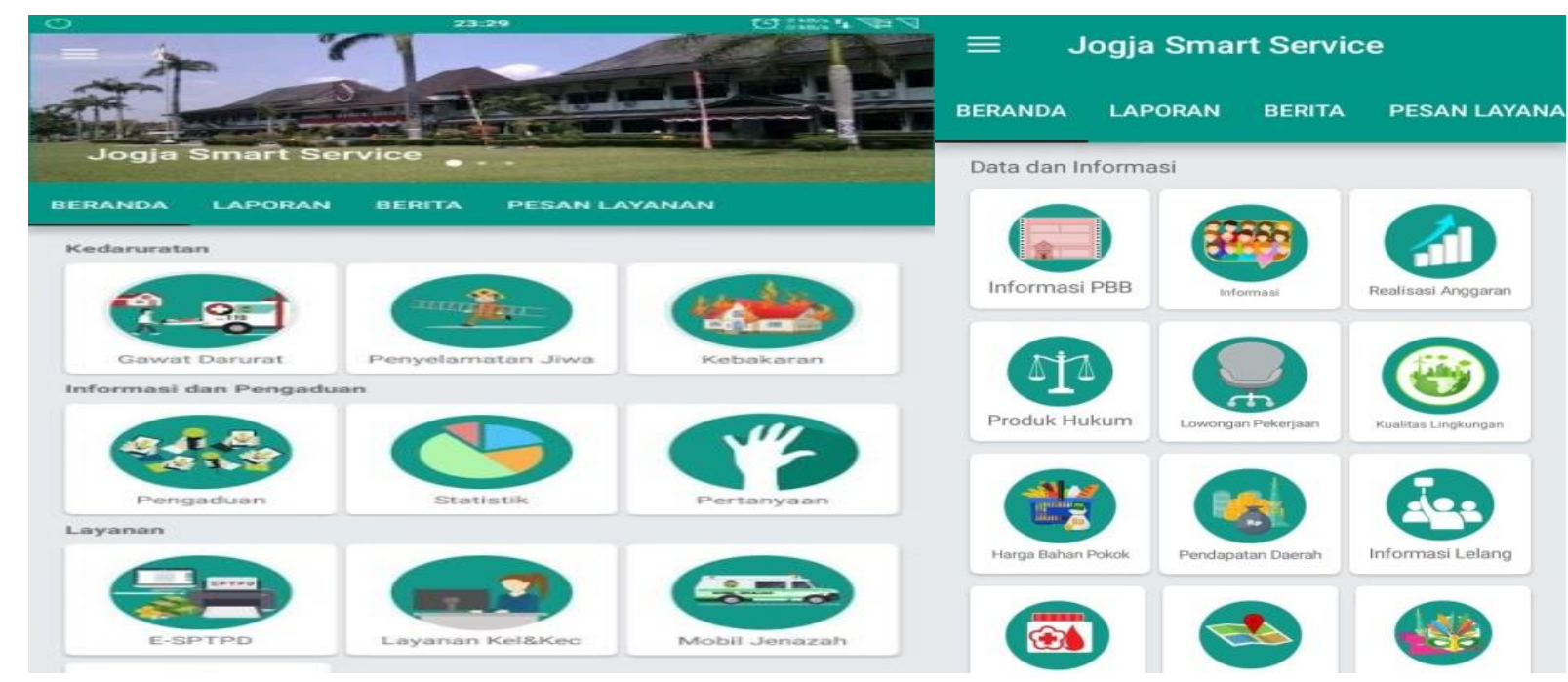

Gambar 2. Layanan Jogja Smart Service

Pengembangan smart city Kota Yogyakarta secara rinci termaktub dalam Peraturan Wali Kota Yogyakarta Nomor 100 Tahun 2018 tentang masterplan pengembangan smart city Kota Yogyakarta tahun 2018-2022.
Adapun tujuan utama dari smart city Kota Yogyakarta bisa tercapai dengan fokus kepada dimensi smart culture, smart tourism dan smart education. Secara detail dijabarkan pada tabel dibawah ini:

61 Kolaborasi Antara PT Gas Negara Dengan Pemerintah Kota Yogyakarta... 
Tabel 1. Tujuan Dan Sasaran Prioritas Program Smart City Kota Yogyakarta

\begin{tabular}{ll}
\hline \multicolumn{1}{c}{ Tujuan } & \multicolumn{1}{c}{ Sasaran } \\
\hline $\begin{array}{l}\text { Meningkatkan transparansi, akuntabilitas, } \\
\text { dan partisipasi dalam pelaksanaan }\end{array}$ & a. Pelayanan publik yang efektif dan efisien \\
pemerintah & b. Manajemen birokrasi yang efisien \\
$\begin{array}{l}\text { Meneguhkan posisi Kota Yogyakarta } \\
\text { sebagai Kota Pendidikan, Pariwisata dan publik yang efisien } \\
\text { pelayanan jasa yang berlandaskan }\end{array}$ & Tourism Branding dan Platform pemasaran \\
keunggulan kompetitif. &
\end{tabular}

Meningkatkan tata kelola lingkungan yang Tata kelola energi yang bertanggung jawab baik, berkelanjutan dan bertanggung jawab. dan proteksi lingkungan yang terintegrasi

\section{Sumber: Data Primer diolah}

Pada Tabel 1 menunjukan hal-hal penting yang harus diperhatikan dalam mewujudkan smart city di Kota Yogyakarta. Poin-poin tujuan dan sasaran program sebagaimana tabel diatas menjadi penting karena identitas yang melekat sebagai ibu kota provinsi sekaligus tujuan pariwisata dan pendidikan baik dari dalam maupun luar negeri. Sehingga kebutuhan atas akses informasi dan pelayanan publik yang efisien menjadi sangat dibutuhkan.

\section{Smart City dan Tata Kelola Pemerintahan Kolaboratif}

Sebagaimana Lucas (2018) dalam mewujudkan smart city tidak bisa hanya dilakukan hanya dengan satu pihak saja dalam hal ini Pemerintah Kota Yogyakarta. Melainkan bekerjasama dengan masyarakat dan swasta sekaligus, setidaknya tercatat sejak dicetuskannya smart city Kota Yogyakarta telah menggandeng beberapa aktor lain diluar pemerintahan, diantaranya: BAZNAS (Badan Amil Zakat Nasional), PMI (Palang Merah Indonesia), Kepolisian, Rumah Sakit, PDAM dan Bank Jogja. Bentuk kolaborasi ini ditentukan berdasarkan tugas pokok dan fungsinya masing-masing, misalnya BAZNAS bertugas mengelola bantuan data dari masyarakat untuk kegiatan sosial dll, Kepolisian menindaklanjuti laporan pelanggaran lalulintas atau kriminaliasi, rumah sakit untuk situasi gawat darurat. Dan seterusnya sesuai dengan jenis layanan yang tersedia di Jogja Smart Service. 
Selain kolaborasi dalam pelaksanaan Pemerintah Kota Jogja pada tahun 2019 telah menggandeng mitra kerja lainnya yakni PT Gas Negara.salah satu tujuan yang fundamental dari dibangunnya kerjasama ini adalah untuk mewujudkan smart economy, smart torism dan smart environment. Selain itu, program kolaborasi ini ini dicanangkan untuk memanfaatkan gas bumi guna memenuhi kebutuhan energi. Perusahaan Gas Negara (PGN) adalah perusahaan nasional (BUMN) dibidang transportasi dan gas bumi, perusahaan ini telah bergerak sejak tahun 1965 diketuai oleh direktur utama yakni Gigih Prakoso Soewarto.

Penandatanganan kerjasama dilakukan pada tanggal 23 September 2019 di Pemkot Yogyakarta. Sebagaimana disampaikan oleh Gigih Prakoso kerjasama ini merupakan bagian dari strategi jangka panjang PGN untuk memperluas pemanfaatan Gas Bumi, melalui kerjasamanya dengan Pemerintah Kota Yogyakarta PGN berharap banyak masyarakat dan pelaku usaha yang dapat menikmati manfaat gas bumisebagai energi yang ramah lingkungan, efisien, dan diproduksi didalam negeri (Reza, 2019).

Alasan lain yang melatbelakangi kerjasama ini yakni latar belakang smart city yang harus dibarengi penggunaan gas bumi yang ramah lingkungan diharapkan dapat meneguhkan iklim kenyamanan bagi para wisatawan maupun masyarakat luat yang sedang bekerja dan menempuh pendidikan di Kota Yogyakarta. Sebagaimana yang disampaikan oleh Wali Kota Yogyakarta yakni Haryadi mengatakatan program smart city merupakan salah satu prioritas Pemerintah Kota Yogyakarta, dan sebagai bentuk tindak lanjut kerjasama ini Pemerintah Kota Yogyakarta menjanjijakn kemudahan perizinan bagi PT PGN untuk membangun infratruktur gas di wilayah Yogyakarta (Reza, 2019).

Rencana pembangunan infrasturktur untuk Gas Bumi mulai dicanangkan mulai Desember 2019, yang mana pembangunan jaringan pipa distribusi Gas sepanjang $500 \mathrm{~km}$, pipa transmisi $528 \mathrm{~km}$ tujuh Liquified Natural Gas (LNG) Filling station untuk kendaraan pengangkut, 3,59 juta sambungan rumah tangga. Selain mencanangkan penggunaan gas bumi sebagai alternative energy, PT PGN juga menjanjikan mewujudkan kebutuhan jaringan untuk mendukung Smart City milik Kota Yogyakarta, yang mana PT PGN memiliki anak perusahaan yang bergerak dibidang telekomunikasi sebagai penyedia fiber optik (FO) yakni PGASCOM. 
Tabel 2. bentuk kerjasama Pemkot Yogyakarta dengan PT PGN

\begin{tabular}{ll}
\hline \multicolumn{1}{c}{ Bentuk Kerjasama } & \multicolumn{1}{c}{ Sasaran dan Program: } \\
\hline $\begin{array}{l}\text { Penandatangannan nota kesepakatan pemkot } \\
\text { yoyakarta dengan pt pgn dilaksanakan pada } \\
\text { tanggal 23 september 2019 }\end{array}$ & $\begin{array}{l}\text { 1. Perluasan penggunaan gas bumi } \\
\text { 2. Mendukung UMKM }\end{array}$ \\
& $\begin{array}{l}\text { 3. Mendorong hotel dan restoran } \\
\text { menggunakan gas bumi }\end{array}$ \\
Pemkot Yogyakarta : & $\begin{array}{l}\text { 4. Pengembangan layanan pgn } 360 \\
\text { degree integrated solution }\end{array}$ \\
PT PGN : & $\begin{array}{l}\text { 5. Perluasan jaringan pipa gas bumi } \\
\text { Permudah pemberian izin oleh pemkot } \\
\text { yogyakarta } \\
\text { Mendukung Smart City Kota Yogyakarta } \\
\text { melalui bidang jasa Nusantara } \\
\text { telecomunicasi nusantara }\end{array}$
\end{tabular}

Sumber: Data Primer, diolah

Tabel 2 menunjukan bahwa bentuk dan sasaran kerjasama antara Pememrintah Kota Yogyakarta dengan PT PGN, program kerjasama ini seyogyanya untuk mewujudkan Smart Invorenment yakni pengelolaan sumber daya alam dan

\section{KESIMPULAN}

Smart City menjadi prioritas program oleh Pemerintah Kota Yogyakarta. Konsep smart city sebenarnya telah dicanangkan sejak tahun 2009 dengan platform UPIK. Namun karena keterbatasan aksestabilitas yang memerlukan kebaruan perangkat sehingga pada awal tahun 2019 Pemerintah Kota Yogyakarta memerkenalkan aplikasi Joga Smart Service aplikasi satu windaws sebagai penggantinya. pemeliharan lingkungan yang cerdas terdiri dari:Protection atau perlindungan lingkungan, tata kelola limbah hasil rumah tangga dan membangun daya saing energy berkelanjutan.

Dari hasil penelitian ini juga ditemukan bentuk dan proses kolaborasi antara pemerintah Kota Yogyakarta dengan Swasta dan juga masyarakat. Pemerintah Kota Yogyakarta berkolaborasi dengan Baznas, Kepolisian, Rumah sakit, dll untuk menunjang pemanfaatan aplikasi JSS. Kemudian pada akhir September 2019. Pemerintah Kota Yogyakarta juga telah membangun kerjasama dengan PT PGN perusahaan BUMN yang bergerak di bidang transportasi dan Gas Bumi. Proses 
kerjasama diawali dengan

penandatanganan nota kesepakatan antara

Pemkot Yogyakarta dalam hal ini Wali

kota Yogyakarta dengan Direktur Utama

PT PGN. Didalam kesepatannya termaktub

bebebarapa poin yakni. Pemerintah Kota

Yogyakarta siap memberikan kemudahan izin kepada PT PGN, dan selanjutnya PT

\section{DAFTAR PUSTAKA}

Annisah. (2017).

USULAN PERENCANAAN SMART CITY: SMART GOVERNANCE PEMERINTAH DAERAH KABUPATEN MUKOMUKO * Smart City Planning Proposal: Smart Governance for Regional Government of Mukomuko Regency. 59-80.

April Insani, P. (2017). Mewujudkan Kota Responsif Melalui Smart City. PUBLISIA (Jurnal Ilmu Administrasi Publik), 2(Smart City), 25-31.

Arrozaaq, D. L. C. (2016). Collaborattive Governance (Studi Tentang Kolaborasi Antar Stakeholders Dalam Pengembangan Kawasan Minapolitan di Kabupaten Sidoarjo). Kebijakan Dan Manajemen Publik, 3, 1-13. Retrieved from http://repository.unair.ac.id/67685/

Emerson, K., Nabatchi, T., \& Balogh, S. (2011). An Integrative Framework for Collaborative Governance. (June 2009), 1-29. https://doi.org/10.1093/jopart/mur011

Fauzan, R. (2016). Strategi Pembangunan Smart City dan Tantangannya bagi Masyarakat Kota. Jurnal Strategi Dan Bisnis, 4(2), 159-176.

Febrian, R. A. (2016). COLLABORATIVE
PGN melalui PGASCOM memberikan akses layanan fiber optik (FO) untuk mendukung program smart city. Selain itu, pemerintah Kota Yogyakarta juga mendorong smart environment melalui program pemakaian gas bumi sebagai alternative energi yang ramah lingkungan.

GOVERNANCE DALAM

PEMBANGUNAN KAWASAN

PERDESAAN ( Tinjauan Konsep dan Regulasi ). II, 200-208.

Ilmiah, J., Jim, M., \& Aceh, K. B. (2017). $D A N$ PENGEMBANGAN PARIWISATA KOTA BANDA ACEH Mulia Dharma $1^{*}$, M. Ilhamsyah Siregar 2 1). 2(1), 134-143.

Manan Sureshchandra, Jaydev Bhavsar, S. J. (2016). Review on Identification of Success Factors for Designing of Smart Cities. IJSTE-International Journal of Science Technology \& Engineering |, 2(09), 125-133. Retrieved from www.ijste.org

Morales, H., \& Meek, J. (2019). administrative sciences Models of Collaborative Governance: The City of Los Angeles ' Foreclosure Registry Program. 1-16.

Nawawi, M., Ilham, M., \& Setiawan, I. (2019). Analisis Penguatan Sumberdaya Daerah Dalam Pelaksanaan Smart Governance Di Kota Balikpapan, Kalimantan Timur. Jurnal Ilmiah Wahana Bhakti Praja, 9(1), 63-74. https://doi.org/10.33701/jiwbp.v9i1.3 20

Oliver, J. (2013). 済無No Title No Title. Journal of Chemical Information and Modeling, 53(9), 1689-1699. 
https://doi.org/10.1017/CBO9781107 415324.004

Rahim, S., \& Haq, N. (2018). Pelaksanaan smart government di kabupaten soppeng. Jurnal Administrasi Publik, 4(3), 297-308.

Sari, M. P., Ilmu, F., Dan, S., \& Politik, I. (2019). No Title.

Setiawan, I. (2017). Implementasi Inovasi Daerah Di Kota Balikpapan. Ilmu Pemerintahan Suara Khatulistiwa, 2(2), 83-97.

Syamsul Arifin dan Utami Dewi, SIP., M. (2018). Collaborative Governance Dalam Program Rintisan Desa Inklusif Di Desa Sendangadi Kecamatan Mlati. E-Juarnal Fisip UNY, 315-332.

Wulandari, W., Purnomo, E. P., Studi, P., Ilmu, M., Yogyakarta, U. M., Brawijaya, J., \& Yogyakarta, D. I.

\section{PROFIL SINGKAT}

Lenny Kurniasari lahir di Lampung Timur, 24 Januari 1998. Buah pasangan dari Bapak Edi Santoso dan Ibu Sulis Styowati. Saat ini, penulis tercatat sebagai mahasiswa Universitas Muhammadiyah Yogyakarta Program S1 Ilmu Pemerintahan tahun angkatan 2017. Aktivitas penulis saat ini adalah sebagai mahasiswa aktif di Universitas Muhammadiyah Yogyakarta tersebut.
(2019). JURNAL ILMU PEMERINTAHAN Kajian Ilmu Pemerintahan dan Politik Daerah. 4(April), 2-3.

Purnomo, E. P. (2019). Smart Government: The involvement of government towards public services in Yogyakarta for Smart Development . INTERNATIONAL CONFERENCE ON PUBLIC ORGANIZATION ASIA PACIFIC SOCIETY FOR PUBLIC AFFAIRS (APSPA) , 455.

Reza. (2019, September 23). PGN dan Pemkot Yogyakarta Bekerjasama untuk Menunjang Program Smart City. Retrieved Desember 29, 2019, from Liputan6.com: https://m.liputan6.com/news/read4 069632/pgn-dan-pemkotyogyakarta-bekerjasama-untukmenunjang-program-smart-city 